Western University Scholarship@Western

Aboriginal Policy Research Consortium International (APRCi)

Fall 2001

Especially good aboriginal art

Vivian Johnson

Australian National University

Follow this and additional works at: https://ir.lib.uwo.ca/aprci

Part of the Art Practice Commons, $\underline{\text { Australian Studies Commons, and the Ethnic Studies }}$ Commons

Citation of this paper:

Johnson, Vivian, "Especially good aboriginal art" (2001). Aboriginal Policy Research Consortium International (APRCi). 396.

https://ir.lib.uwo.ca/aprci/396 
This article was downloaded by: [University of Western Ontario]

On: 07 December 2012, At: 07:36

Publisher: Routledge

Informa Ltd Registered in England and Wales Registered Number: 1072954 Registered office:

Mortimer House, 37-41 Mortimer Street, London W1T 3J H, UK

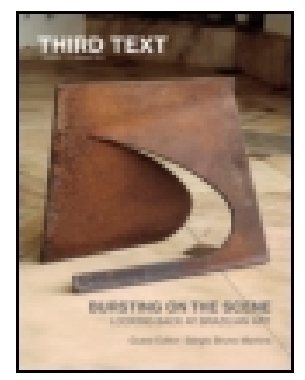

\section{Third Text}

Publication details, including instructions for authors and subscription information:

http:// www.tandfonline.com/loi/ctte20

\section{Especially good aboriginal art}

Vivian J ohnson ${ }^{\text {a }}$

${ }^{\text {a }}$ Senior ARC Fellow at the Centre for Cross Cultural Research, Australian National University,

Version of record first published: 19 J un 2008.

To cite this article: Vivian J ohnson (2001): Especially good aboriginal art, Third Text, 15:56, 33-50

To link to this article: http:// dx. doi.org/ 10.1080/09528820108576927

\section{PLEASE SCROLL DOWN FOR ARTICLE}

Full terms and conditions of use: http://www.tandfonline.com/page/terms-and-conditions

This article may be used for research, teaching, and private study purposes. Any substantial or systematic reproduction, redistribution, reselling, loan, sub-licensing, systematic supply, or distribution in any form to anyone is expressly forbidden.

The publisher does not give any warranty express or implied or make any representation that the contents will be complete or accurate or up to date. The accuracy of any instructions, formulae, and drug doses should be independently verified with primary sources. The publisher shall not be liable for any loss, actions, claims, proceedings, demand, or costs or damages whatsoever or howsoever caused arising directly or indirectly in connection with or arising out of the use of this material. 


\title{
Especially Good Aboriginal Art
}

\author{
Vivian Johnson
}

1 Eric Michaels, 'Bad Aboriginal Art', Art and Text 28, 1988, pp 59-60.

2 Papunya Tula: Genesis and Genius, $\mathrm{H}$ Perkins and $\mathrm{H}$ Fink, eds, Art Gallery of NSW in assoc. with Papunya Tula Artists, 2000.

3 Water Dreaming at Kalipinypa', 1972, broke previous auction sales records for Aboriginal art when it sold from Sotheby's 'Important Aboriginal Art' Melbourne, June 30, 1997, (Lot 15), for $\mathrm{A} \$ 206,000$ and then again at Sotheby's 'Aboriginal Art', Melbourne, June 26, 2000, where it sold for A $\$ 440,000$ (hammer price) Johnny Warangkula had the last word: 'I am number one. I am the winner. I am the boss of my country and I do the best paintings.' Johnny Warangkula Tjupurrula quoted in The Australian July 1997.
I want to consider the curious fact that almost nothing of this work is ever designated bad - a lacuna which would not seem to make it easy to sell anything as especially good either.

If Aboriginal art still remains immune to critical attack so, ironically, does Eric Michaels' famous essay which first drew attention to this state of affairs. The canonical status of 'Bad Aboriginal Art' was recently brought home to me by the inclusion of its 1988 publication date in the draft Chronology of the catalogue of 'Papunya Tula: Genesis and Genius', the first major retrospective of the founding Western Desert painting company. ${ }^{2}$ In 1971, the founders of the Papunya Tula Artists company took up their brushes in the remote desert community of Papunya and opposed the might of the assimilationist regime with their exquisite paintings of ceremonial grounds and Dreaming narratives proclaiming the living culture of the Western Desert peoples. After thirty years, they were accorded the ultimate mark of recognition by the Australian art establishment for their superlative artistic achievements - notwithstanding the continued elusiveness of criteria on which to base such a judgement! Mounted at one of Australia's premier art institutions during the Sydney 2000 Olympic Games - the exhibition was a heavily symbolic moment in Australian postcolonial history - not least for its conflation of a business enterprise with an art movement. As the Papunya Tula painters always knew, High Art is a financial as well as a cultural status. Indeed the quest which Michaels' article initiated may have ended after all - at Sotheby's Melbourne salesroom in June 1997 and then again in June 2000, when money spoke, anointing Johnny Warangkula's 'Water Dreaming at Kalipinypa' $1972^{3}$ in particular and early Papunya boards in general as the new touchstone of Good Aboriginal Art. Hettie Perkins, the Indigenous curator of 'Genesis and Genius', evidently thought so: more than sixty works from the first two years of painting at 


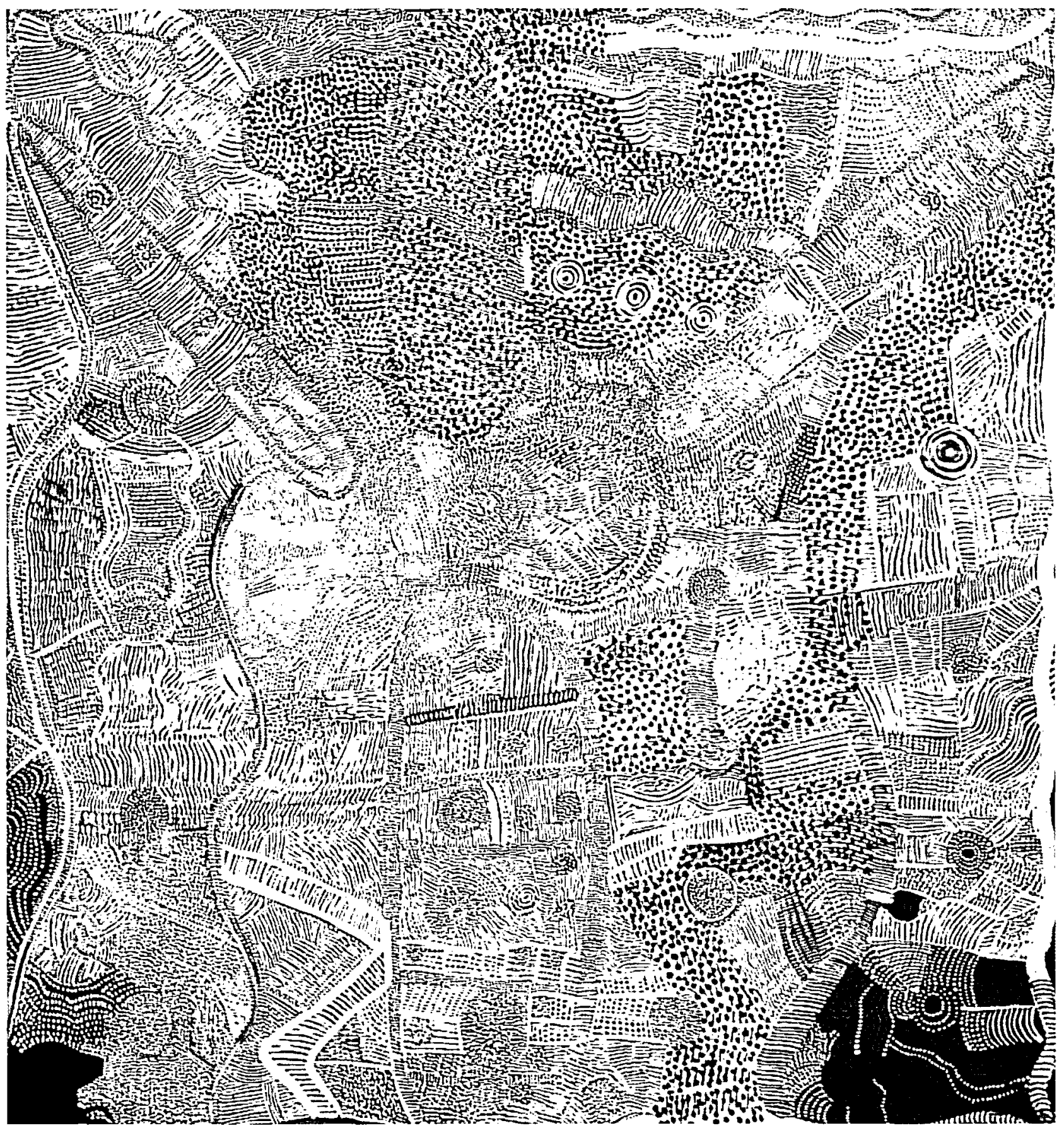

Johnny Warangkula Tjupurrula, Water Dreaming at Kalipinypa, 1972, synthetic polymer paint on composition board,

$80 \times 75 \mathrm{~cm}$, Private Collection. Photo Courtesy Art Gallery of NSW 
4 Eric Michaels, op cit, p 67.

5 Until the establishment of painting enterprises at Yuendumu, Mt Allen and Napperby in the mid ' 80 s, Western Desert painting was largely confined to Papunya and the Pintupi homelands communities of Kintore and Kiwirrkurra established in the early '80s, all serviced by Papunya Tula Artists, and was universally known as 'Papunya painting'.
Papunya graced the walls of the Art Gallery of NSW in the opening courts of the exhibition, far more than from any other period in the movement's history.

'Bad Aboriginal Art' was the only piece of critical writing mentioned in a survey spanning the entire history of Aboriginal art-making in Central Australia. Whether it was there as an event in the story of Papunya Tula Artists, or as part of its wider historical contextualisation, was not indicated in the draft sent out to a number of the catalogue's contributors for comment. On both counts, its inclusion would have been appropriate, for its influence has been profound, both nationally and internationally - not excluding 'Papunya Tula: Genesis and Genius' itself. Its presence would also have been some acknowledgment of the part that art world debates like those generated by 'Bad Aboriginal Art' have played in the history of Western Desert art. Yet I was not surprised to see that it had been culled from the Chronology's final version. Michaels had some pretty uncomplimentary things to say in this essay about 'that redundant, recognisable, brand name product: Papunya Tula'.4 He is so uncomplimentary at times that it should have been no mystery to anyone all these years what Michaels thought was bad Aboriginal art - had not such a suggestion, even in 1988, sounded so absurd as to be unfathomable to his readers. Papunya Tula was then, as it is now, the touchstone of good Aboriginal art, the standard against which others are judged.

Indeed, that was in a sense what Michaels had against 'Papunya painting',

Installation shot, 'Papunya Tula: Genesis and Genius', Art Gallery of NSW, August-November 2000.

Foreground: Ground painting by Bobby West Tjupurrula, Warlimpirringa Tjapaltjarri , Charlie Tjapangati,

Kenny Williams Tjampitjinpa. Photo Courtesy Art Gallery of NSW
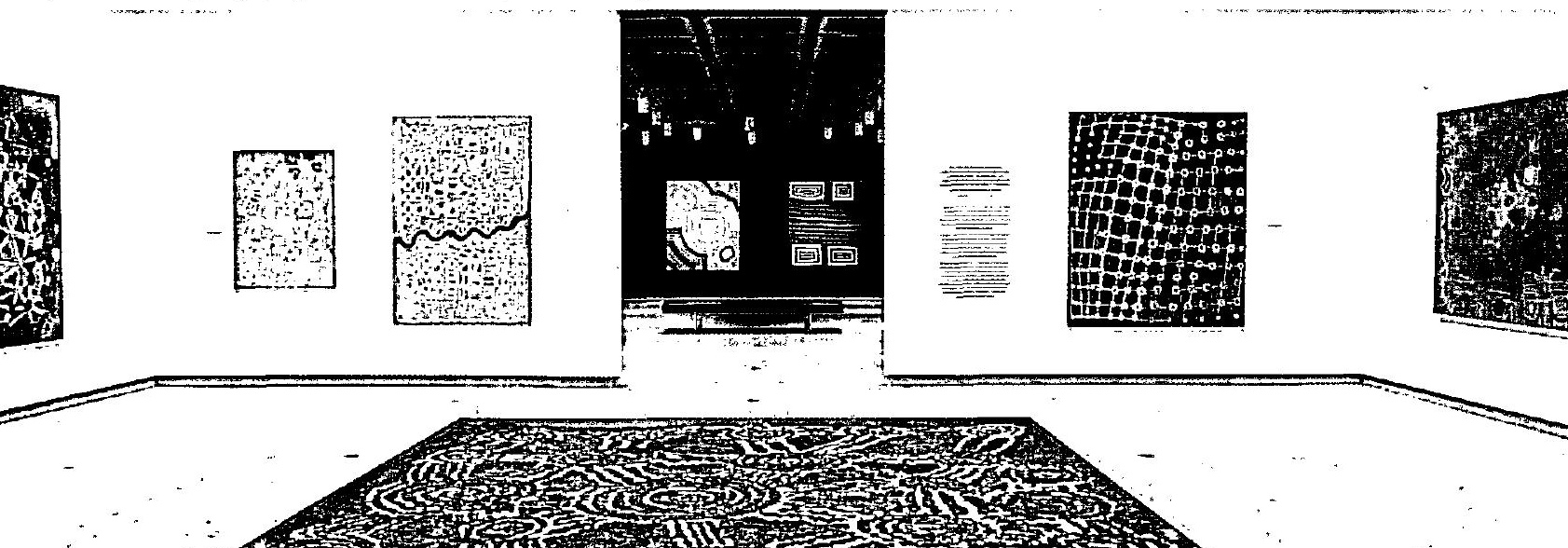
whose canonical status was driven home in no uncertain fashion to the Yuendumu painters, with Michaels apparently in attendance as their 'advisor and in-house critic $^{\prime 6}$ when representatives of the government's Aboriginal art marketing organisation Inanda Holdings visited the recently formed Warlukurlangu Artists company:

The original pronouncement by designated evaluators was that the paintings weren't very good.[my emphasis] When the official experts of the Inanda Holdings Pty Ltd (an Aboriginal Affairs operation then engaged in attempting a monopoly on all non-urban Aboriginal art marketing) first saw these paintings, they suggested that the artists might wish to spend some time at Papunya settlement to learn their craft and improve their technique - and that Federal funds that might be found for such training.

'Bad Aboriginal Art' - or at least the covert assault on Papunya Tula's credentials which is its sub-text - almost certainly had its origins in this incident. Michaels' indignation at such patronising treatment of the senior men of Yuendumu is palpable and contagious. The reader cannot help feeling incensed at the fiercely proud Warlpiri being told that their paintings of their Dreamings weren't as good as the Papunya painters' paintings of theirs. Or the preposterous suggestion that these senior community and ceremonial leaders should approach their counterparts in another community and ask for art lessons!

\section{NOT VERY GOOD ABORIGINAL ART}

Michaels' advocacy of Yuendumu painting in 'Bad Aboriginal Art' anticipates the role which anthropologists took on over the 1990s in Aboriginal art as advocates of the paintings of their respective informant groups. Their scholarly essays validated these works for the marketplace as authentic Aboriginal art just as they had previously validated the purpose-made shields and boomerangs purchased from their research subjects for museum collections as authentic ethnographic artefacts. Michaels adopts a highly original and occasionally paradoxical mix of postmodern metaphor and anthropological orthodoxy, but the over-identification with one's host community displayed in his attacks on Papunya is one of the occupational hazards of the anthropological profession. Unlike Michaels, his colleagues do not usually make a point of slagging off the opposition! But in the absence of objective criteria of good or bad Aboriginal art, he needs Papunya Tula to be the negative against which the virtues of Yuendumu painting can be positively defined.

For Michaels, Yuendumu painting is everything Papunya Tula is not. It is 'bright bold colourful and messy's to Papunya Tula's 'muted' 'cerebral' 'tasteful' and 'meticulous'. Actually this is a pretty apt summation of Papunya Tula's 'signature style' at the time Michaels wrote - so apt in fact that his critique proved very effective in the short term. In the years following the publication of 'Bad Aboriginal Art', Papunya Tula's formerly incontestable market leadership waned in the face of strong competition from new painting

6 Eric Michaels, op cit, p 68

7 Ibid, p 66.

8 Ibid, $\mathrm{p} 68$. communities across the Western Desert - and a marked shift of buyer preference towards the 'atechnical technique' favoured by the Yuendumu painters and those who came after them. What I did not grasp until now was the relationship of Michaels' 'talking down Papunya-talking up Yuendumu' 
sub-text to his central thesis of the need to replace the 'dangerous fantasy' ${ }^{\prime 9}$ of authenticity with a discourse of cultural authority (the continued validity and pertinence of which is the underlying cause of the paper's canonisation). The epithet 'brand name' carries more than the obvious implication that the Papunya painting style is predictable and formulaic. Brand names usually figure in the anthropological literature as signifiers of cultural decline. Brand names are the antithesis of cultural authority, which Yuendumu painting maintains, while Papunya Tula feeds its audience fantasies of its own making:

Were the Papunya painters totally passive, while their art advisers conspired with the market to invent Papunya Tula aesthetics, to define both the 'good' and the 'tasteful' and to construct the painters' authenticities in the process? ${ }^{10}$

For Michaels, the question is purely rhetorical. Those mauve-faced art advisers ${ }^{11}$ are the real villains of his piece. If it seems strange for him to be targeting these beleagured defenders of Indigenous ownership and control, remember that in Michaels' day it was still possible for a government marketing organisation like Inanda Holdings to conceive of having a monopoly of 'non-urban' Aboriginal art. Government sponsored Aboriginal art marketing operations are now a thing of the past, in an industry increasingly shaped by the interests of the private sector. But in the late 1980s the handful of private dealers hanging out in Alice Springs or making desperate forays to the remote settlements only to be run out of town by indignant art advisers, were as yet an irritant rather than a threat, tellingly designated 'poachers' on the community art centres' undisputed territories. The industry norm was artists working exclusively for art centres staffed by art advisers, one of whose tasks it was to mediate between the painting groups of the remote communities and the marketplace.

But when Michaels questions 'the legitimacy of certain technical choices generally regarded as externally, and perhaps unnecessarily influenced', ${ }^{12}$ the operative word is 'unnecessarily'. There were apparently no mauve faces at Yuendumu, where art advisers do not fabricate 'authenticities' but simply respond to the resonances between Western Desert cultural values and contemporary art discourse. As a result, Yuendumu work would 'look at home in any contemporary New York gallery without even so much as a program note to describe its Aboriginal sources': ${ }^{13}$ Michaels' personal criterion of Good Aboriginal Art, which he declares 'wildly subjective' knowing full well that Australia's cringing cultural elites will be heavily influenced by it.

In this respect, Michaels would have approved of 'Papunya Tula: Genesis and Genius'. A quarter of the works were titled 'Untitled'. Buried in the introductory notes to the List of Works on p 276 of the catalogue is the explanation that: 'Artists do not in general give titles to their works.' Strictly speaking then, they should all be titled 'Untitled'. However in Contemporary

9 Ibid, $\mathrm{p} 72$.

10 Eric Michaels, op cit, $\mathrm{p} 67$.

11 'Arts advisors can deny influencing indigenous art until they are mauve in the face', ibid, p 67.

12 Ibid, p 68.

13 Iibid, $\mathrm{p} 69$.
Fine Art circles, the title 'Untitled' connotes a work of pure abstraction, for which indeed many of the works in the exhibition might, in different circumstances, have been mistaken. The annotations of the paintings supplied by Papunya Tula Artists indicated they were not abstracts, but works of figuration depicting sites, narratives and ceremonies associated with the artist's particular Dreamings. However, it was made rather difficult for the reader to establish this by consulting the annotations as they perused the catalogue, because the Plates were at the front and the annotations were included in the List of Works at the back, which was organised not in order of their appearance in the 
14 Ibid, p 69.

15 Ibid, pp 69-70.

$16 \mathrm{G}$ Bardon, Aboriginal Art of the Western Desert, Rigby, Australia, 1979, p 14.

17 Eric Michaels, op cit, $\mathrm{p} 67$. catalogue but under artists' (first) names. One had to flick back and forth and search through the List of Works under the appropriate artist's name to find them. Except for references to sites or Dreamings in an art adviser or museum curator's title (which 'Papunya Tula: Genesis and Genius' had retained 'as part of the history and provenance of the paintings'), the information in the annotations was not included in the exhibition's signage for any of the paintings. And since the catalogue was not available until a month into the exhibition, nor was it part of these early visitors' experience of the paintings. (Responses were nevertheless uniformly rapturous.)

To prove his point about Yuendumu painting, Michaels offers an anecdote about the time he interrupted the painting of the first large canvas to be produced at Yuendumu to criticise a section of the background dotting. It was the work of a man who had recently returned from Papunya, where '..he had joined in on a painting work (not at all an unusual reciprocal cultural exchange)' - and 'brought back the dotting style with him' ${ }^{14}$ In Michaels' view this man's 'orderly rows of contrasting dots in the characteristic [Papunya] palette... imparted a very unwieldy look to that corner of the painting..' and nervous about the fate of such a 'major project', 'I intervened.' :

I casually remarked to the senior painter (not the offender) 'what he thought' about the dots. Were they part of the Dreaming/Story (jukurrpa/jimi)? No, of course not. He went over the story again, tracing the large dark figures centrally placed in this canvas. Some time later, I remarked that it was hard to see the story in the Papunyalooking section: there were so many colours, the dots looked like jukurrpa (text). Europeans might get confused looking at the picture. I held my breath.

Everything stopped. With the grand gestures I associated with the senior painter, a pronouncement was made. My Warlpiri is not good enough to follow the specifics, but a full ten minutes was spent discussing the matter which resulted in a paintbrush being applied to some of the offending section, producing a more consistent and less defined area of fill. The painting subsequently set a new record for Yuendumu prices and now hangs in the Australian National Gallery - whatever that tells us about our example, and whatever questions it raises about interventions. ${ }^{15}$

There is something about this description strongly reminiscent of Geoffrey Bardon's account of his intervention in the Papunya School mural project to obtain the removal of elements of figuration which he considered to be 'non traditional'. ${ }^{16}$ Michaels alludes to this incident in 'Bad Aboriginal Art', finding in it 'contradictory evidence of an enforcement of "traditionalism"' ${ }^{17}$ But if he also fancied himself as a kind of latter day Geoff Bardon, occupying a similarly seminal position in the birth of the painting movement at Yuendumu, he would not be the first or the last in Western Desert art to do so. And he was like Geoff Bardon in wanting to keep the painters off the subject of men's business and preferring to focus on helping them succeed as artists. It was the advice Michaels offered about how the painting would go down with Europeans that seems to have grabbed the old men's attention and galvanised them into action to re-work the offending section.

The move to large canvases happened quickly at Yuendumu, and this episode occurred within a few months of the formation of Warlukurlangu Artists in August 1985. The painting in question was 'Munga Star Dreaming: this is why we sleep at night' by Paddy Japaljarri, Jimmy-ja Jungurrayi, Larry Jungurrayi and Paddy Jupurrula (and assistants). It formed the centrepiece of 


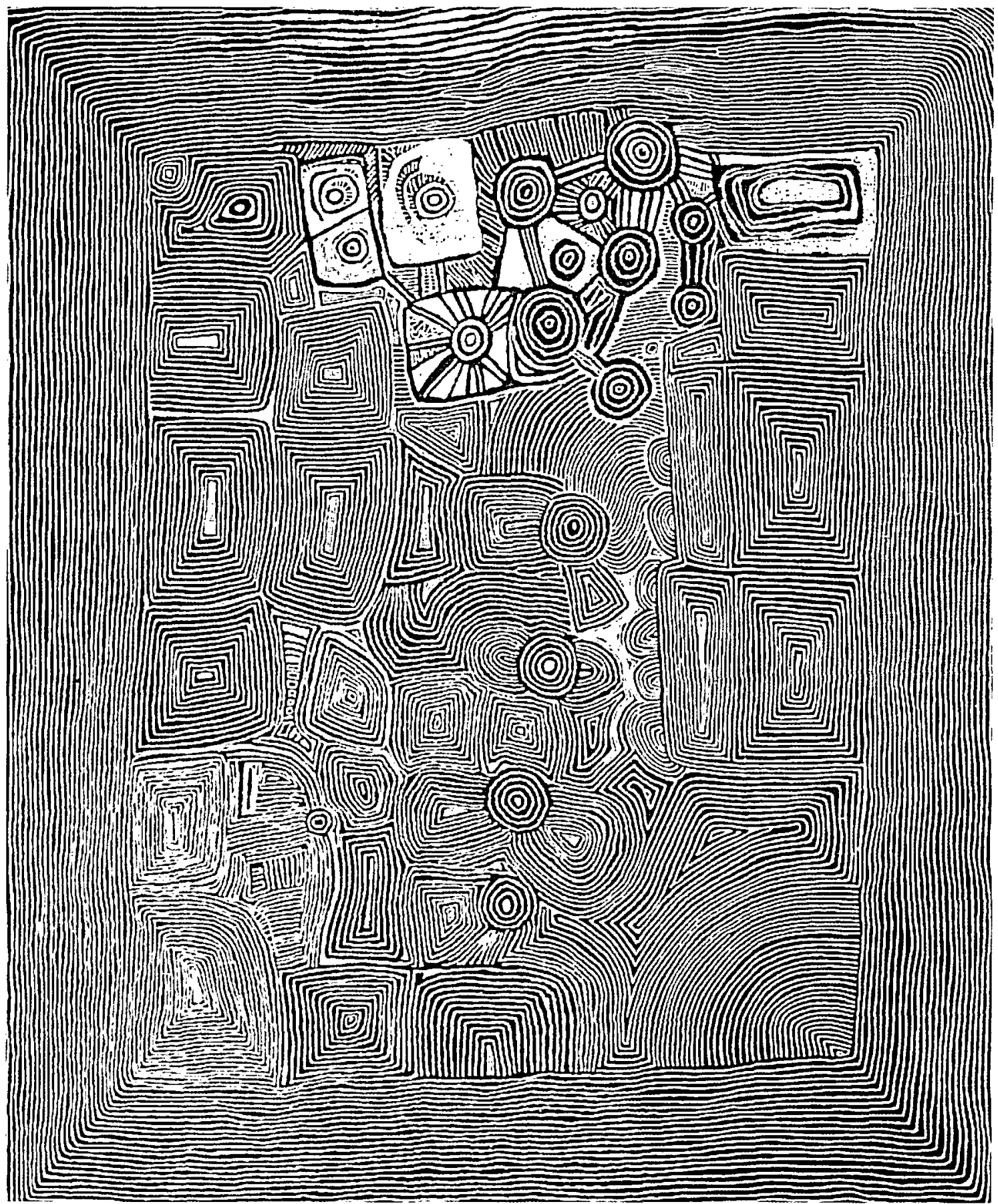

Kiwirrkuar Men's Painting:

Bobby West Tjupurrula, Brandy Tjungurrayi, Charlie Wallabi Tjungurrayi, Charlie Ward Tjakamarra,

Johnny Yungut Tjupurrula, Kanya Tjapangati, Patrick Tjungurrayi, Tjumpo Tjapanangka, Walala (Robert) Tjapangati

Untitled, 1999, synthetic polymer paint on canvas, $257 \times 212 \mathrm{~cm}$, private collection. Photo Courtesy of Papunya Tula Artists and Art Gallery of NSW. This painting was sold for $\$ A 300,000$ at the Western Desert Dialysis Appeal Auction, November 2000 
an exhibition at the Hogarth Galleries in Sydney in December 1985 which was the first significant exposure of Yuendumu painting to the Australian art world. The anonymous statement in the catalogue was almost certainly the work of Michaels, perhaps the initial formulation of the views elaborated in 'Bad Aboriginal Art'. It contrasts the Yuendumu works with other desert paintings (which in 1985 could only mean Papunya Tula paintings) as 'less contrived, freer and less stylised...the effect ... more contemporary, even postModernist, in the striking application of colour'. (Note the absence of references to Aboriginality.) In 1988, 'post-Modernist' was not the tired catchcry it has since become. To an Australian art public newly introduced to the term by the 1986 Biennale of Sydney, it was the epitome of art theoretical sophistication - and contemporaneity. But the purchase of 'Munga Star Dreaming' by the Australian National Gallery at a record price for a Yuendumu painting to that point ${ }^{18}$ is not necessarily a vindication of Michaels' artistic advice, not even as an ingenious marketing strategy for the moment in art world discourses at which it was introduced. The rush to acquire the first paintings to come out of each new Western Desert community to join the art movement (which may have ensured strong sales at the first Yuendumu show regardless of his intervention), had more to do with neo-primitivism than neoexpressionism. (As may the prices currently being fetched for early Papunya boards.)

\section{IN DEFENCE OF PAPUNYA PAINTING}

Unlike Yuendumu, where the painters launched into large canvases like 'Munga Star Dreaming' almost straight away, the beginning of 'market painting' at Papunya involved small boards and the very fine brushes supplied by Geoffrey Bardon. From this, the artists worked up to bigger sizes initially by loosening their style, producing in the years following Bardon's departure larger boards and small canvasses with the same freewheeling gesturalism that Michaels associates exclusively with Yuendumu. They were in the throes of inventing the secularised painting language in which hundreds of Western Desert artists, including the Yuendumu painters, would a decade later begin to paint their Dreamings. Papunya Tula's artists were not exposed to the challenge of working on a large scale until six years into the art movement, when Clifford Possum was presented with the $6^{\prime} \times 6^{\prime}$ canvas which with his brother Tim Leura's assistance became the masterpiece 'Warlugulong' for the cameras of the 1976 BBC documentary 'Desert Dreamers'. But 'masterpiece' is a rather poor word to describe something so far removed from the fetishes of European art history as the rich compendiums of Western Desert culture, encyclopedic in the range and complexity of their contents, for which 'Warlugulong' 1976 was the prototype. Papunya Tula possessed only a handful of big stretchers in the late 1970 s and only one really large one, the much sought after $8^{\prime} \times 12^{\prime}$, referred to by all the artists when it came time to demand their turn at it as 'motorcari one'. The artists' response to these epic proportions and the example of other artists who had preceded them in the task was to delineate vast networks of Dreaming sites and stories across the canvas, laying

18 For the record, around $\$ 3000$ - while Papunya paintings were on average about twice as expensive. out their custodial responsibilities like a deed of title to their personal 'country'. Each painting took upwards of a month to complete, even with the aid of ritually appropriate assistants from amongst the other artists. Perhaps fifty such large canvases were produced by the Papunya painters in the late 1970s 
19 Eric Michaels, op cit, $\mathrm{p} 66$.

20 Ibid, p 67.

21 cf The Art of Clifford Possum Tjapaltjarri, Vivien Johnson, G\&B Arts International, Craftsman House, Australia, 1994, p 40 and pp 141-6.

22 'That's my idea. I give everybody idea - Not them white men colour. No - them native colour them red one, them white one, black one. I start kulpa, karrku, nguntju nguntju, kantawarra - that what I been thinking idea - from four paint red one, and a yellow, black one white one - from four paint I mix'm - 'Nother four more, I mix from white another four more from my idea they all got it.' (Ibid, p 144).'Clifford Possum's version of events directly contradicts Michaels' thesis of art adviser manipulation in the creation of the Papunya palette. and early 1980s, the culmination of the years of stylistic refinement and experimentation that lay behind the development of the mature Papunya style whose most perfect expression they are. The creation of this body of 'master works' was a landmark not only in the development of each artist but in Papunya painting as a whole. The artists' dedication to their production (and their advisers' disregard of the commercially suicidal overheads involved) helped maintain the art movement's momentum through an otherwise bleak period. People who witnessed any of these paintings being created speak of visionary moments of discovery and inspiration, from which the artists could progress to other significant moments, but which could not themselves be repeated - at least not by them. Yet it is for this'Golden Age' of Papunya painting (to use the same misleading art historical terminology) that Michaels reserves his most scathing comments, in the following 'hypothetical reconstruction' ${ }^{\prime 19}$ of the emergence of the signature Papunya style:

As Papunya art became recognised, it obviously received advice on materials justified by arguments of durability and suitability for the museum/collector market it was attracting. Canvas boards and school poster paints would no longer do. What evolved was the use of raw linen and thinned acrylics. This produced a comparatively flat, stained surface. There must have been some restriction on paint colours during the late '70s, emphasising an ' authentic ' earth palette: red, yellow and white ochres, browns and pinks (what Brisbane's upholsterers call 'autumn tonings')... The look was muted, cerebral, and undeniably tasteful in exactly the way that tourist Aboriginal Art - black, red and yellow cartoons (also the product of an invented palette) - was not. By 1980 there had arisen an unerringly recognisable Papunya Style. Not all painters adhered to the style and some truly original works were produced that don't at all fit this description. But to the extent that an industry came into being ... it produced that redundant, recognisable, brand name product: Papunya Tula. ${ }^{20}$

Michaels overlooks the powerful political symbolism of the Papunya painters' use of 'Aboriginal ' colours as primary pigments for their painting enterprise, particularly in the early years when the painters and their supporters were in sharp conflict with the assimilationist regime. When painting started at Papunya, Harold Thomas had barely designed the Aboriginal flag. Its red black and yellow were not yet the definitive 'Aboriginal ' colours which a generation of land rights marches and demonstrations for Aboriginal rights had made them by 1988. For art audiences of the early 1970s, red ochre, yellow ochre, white and black were marked as 'Aboriginal' colours - Michaels' jibe about 'Brisbane upholsterers' autumn tonings' notwithstanding. Painting in them was an integral component of Papunya Tula's founding concept of an' indigenous $\operatorname{rrt}^{\prime} .^{21}$ There was an outbreak of rainbow palettes at Papunya corresponding to the aforementioned period of experimentation when the artists first changed over to acrylics and canvas, which was indeed similar to the free use of colour Michaels witnessed in the early years at Yuendumu. But the Papunya painters emerged from this period of experimentation as sophisticated colorists who preferred the restricted Papunya palette and the freedom it gave them to mix any combination of the four basic pigments and still have perfect tonal integration. ${ }^{22}$ These practices went back two decades when Michaels wrote, and half a century if you count the work of the Hermansburg watercolourists, with which many in the founding group of painters at Papunya were familiar. Michaels' judgement of the 'alienness' of these ideas 


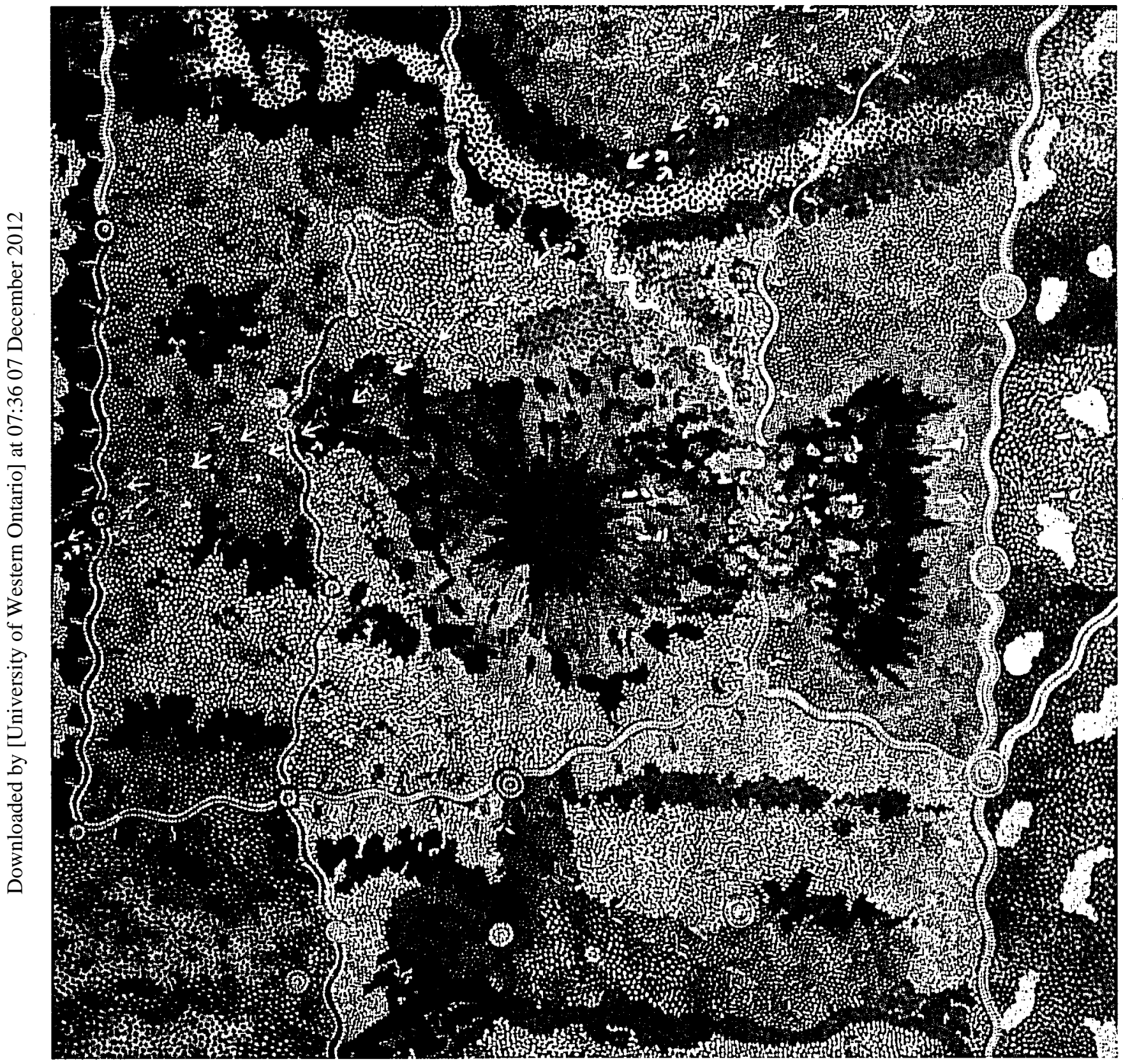

Clifford Possum Tjapaltjarri and Tim Leura Tjapaltjarri, Warlugulong, 1976, synthetic polymer paint on canvas,

$168.5 \times 170.5 \mathrm{~cm}$, collection: Art Gallery of New South Wales, Photo Courtesy Art Gallery of NSW 
23 Eric Michaels, ‘Bad Aboriginal Art', Art and Text 28, 1988, p 68 . generalises his Yuendumu informants' experience (which did not include these things) over the whole of Western Desert society. Michaels also greatly overstates the degree of recognition Papunya Tula Artists enjoyed during the long night of 1970s Australian culture, through which the pioneer Papunya painters laboured on in the face of the indifference of their prospective markets. The thinned primer and paint which gave Papunya painting of the 1970s and early 1980s a stained canvas look, and Papunya Tula's practice in these years of giving out only the four basic colours, probably in the end came down to the fact that painting materials were scarce and had to be extended by watering down. This explanation receives support from the extended range of colours used by Papunya Tula Artists now that the company can afford to maintain it, as well as the emergence of new styles of painting like the Kintore old ladies who can 'pile on' the paint like nobody else in the Western Desert!

The mythological text remained hidden and obscure, which was fine with the painters who at first had great difficulty (according to Bardon) in keeping secret designs out of the canvases and off the market. ${ }^{23}$

This sentence contains the only reference in 'Bad Aboriginal Art' to the controversies which attended the birth of the art movement at Papunya. For all his eccentric disinterest in secret ceremony, Michaels uses the old anthropologists' trick of stating his informants' current views as if they were the truth for all time of their world. The old men of Yuendumu only told him what they wanted

Installation shot, 'Papunya Tula: Genesis and Genius'Art' Gallery of NSW August-November 2000, left to right, works by Tommy Lowry Tjapaltjarri, Clifford Possum Tjapaltjarri and Anatjari Tjampitjinpa. Photo Courtesy Art Gallery of NSW
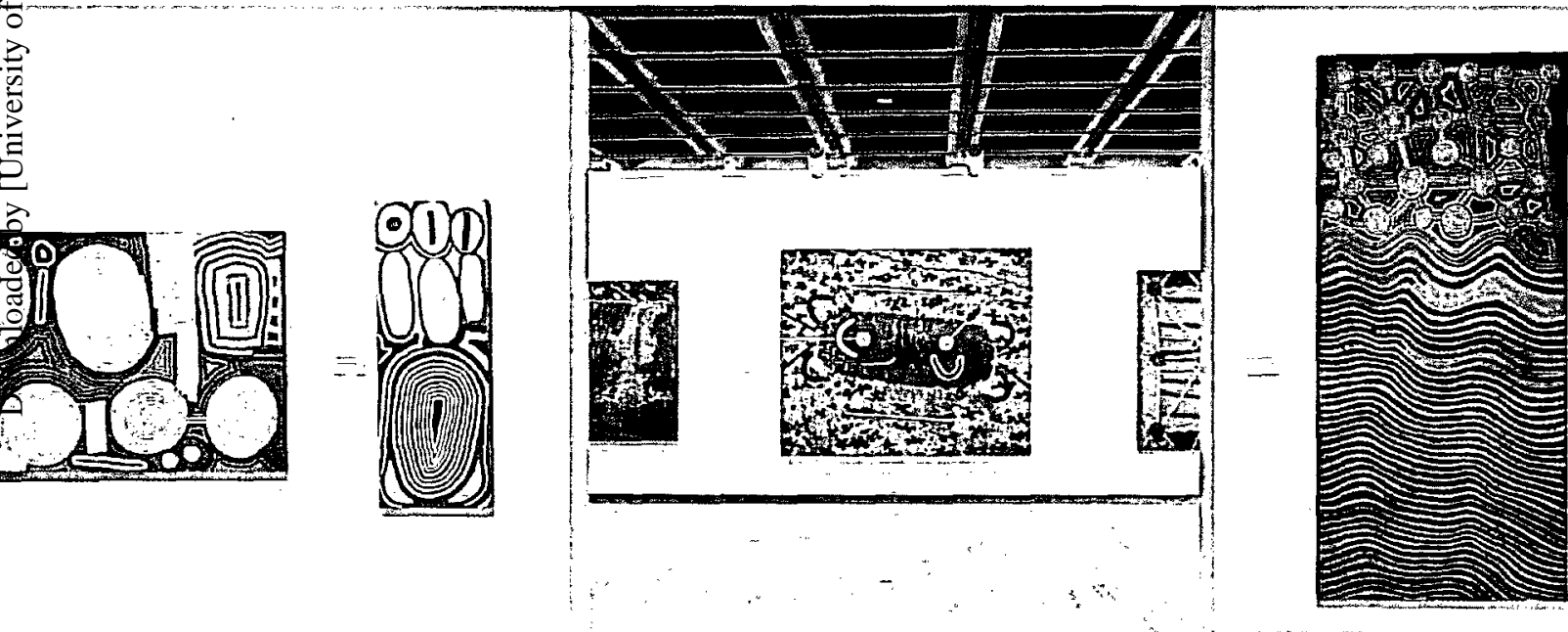
24 'I was at Yuendumu at the time and I heard that all the Papunya old people been start doing the painting on the masonite. They were saying Yuendumu mob you know - 'They shouldn't do that. Giving away all your Dreamtime to white people.' They thought it was really bad. That's Aboriginal way, strict law way. They shouldn't do that in the first place, do painting and show to the white people. They should've leave it, but it's too late now.' Michaels Nelson in Michael Jagamara Nelson Vivien Johnson, Craftsman House, Sydney, 1997, p 33.

25 Eric Michaels, op cit, p 72.

26 The Warlpiri were not alone in their opposition to what was happening at Papunya. To the south, the Pitjanjatjara were bitterly opposed, and had written in formal complaint to the Aboriginal Arts Board to protest the Board's funding of an enterprise which disclosed their sacred-secret designs to the uninitiated. To the west, it was the same story. In the early years of the Pintupi Homelands community established at Kintore in 1981, it was decided that painting would not be permitted on outstations over the West Australian border, about $20 \mathrm{~km}$ west of Kintore, in order not to offend sensitivities on this point of their westerly neighbours and countrymen. him to know. Evidently Michaels was not aware that some of the very same old men explaining Western Desert paintings to him as objects within the Warlpiri value system, had been vehemently opposed to the painting movement when it started at the neighbouring settlement of Papunya a decade and a half before, disowning it as sweepingly as they now claimed ownership of it. ${ }^{24}$ It was seen as a measure of how bad things must be at Papunya that people there should have resorted to such desperate measures as painting their Dreaming designs and selling them to whitefellas.

As the application of tribal visual traditions millennia old to a western art medium, Western Desert painting always was - in intention at least 'establishment art ', affirming the truths and values of its culture, like the preRenaissance religious art of Europe. But when it began, Papunya painting was perceived at Yuendumu and indeed within most of Central Australian Aboriginal society as profoundly anti-establishment. Michaels' articulation of the old men of Yuendumu's mid 1980s position on the painting movement as applicable across all of Western Desert culture contravenes his own requirement that works 'be judged first and foremost in terms of the social practices which produce and circulate them'. ${ }^{25}$ For the early Papunya boards, an anomaly in his speculative history of Papunya Tula, are expressive of the awe which the artists presumably felt at being the first to take what was obviously a radical step, judging from the reaction of their counterparts across the Western Desert. ${ }^{26}$ Things were indeed desperate in Papunya in those early days, desperate enough for the tribal authorities of that community to contemplate - not selling their culture to the whitefellas for tins of tobacco (they knew it was worth much more than that), but making permanent portable records of it - and supporting this activity through their sale as art. The secretsacred controversy to which Michaels alludes undoubtedly exercised a decisive impact on the development of the secularised painting language of contemporary Western Desert art. But it may have been just the most tangible focus people could find at that time for their deep feelings of disquiet about what the Papunya painters were doing. For all the initial furore over this issue, a more fundamental question as the years went by turned out to be collective rights of ownership in the designs and Dreaming trails depicted in the Papunya paintings: the very issue which the old men of Yuendumu sought to highlight in their disclosures to Michaels.

When the Dreamings pass through another tribe's lands, custodianship passes into other hands. By proclaiming only the Papunya painters' rights to the Dreamings, their paintings had inadvertently torn the fabric of Western Desert society. The tear could be mended by the Papunya painters desisting from their art - or the rest of the Western Desert joining them. In time, this latter scenario came to pass as the Papunya artists' success in the contemporary art world (and the resources this gave them to resettle tribal homelands) vindicated their actions to their countrymen. The old men of all the tribes came to the only conclusion they could at this point: they threw the weight of their authority behind the painting movement - and they themselves began to paint. Overnight the antisocial image of the painting movement in Western Desert society was transformed. It became instead a proud affirmation of Western Desert cultural values for the rest of the world - and a confirmation of the power of the Dreaming to look after its own.

Through its dissemination in influential forums like the 'Dreamings' exhibition which toured the United States in 1988-9 and 'Aratjara' which toured European venues in 1993, this view of Western Desert art has become 
the official version of events for the white cultural establishment also, bolstered by Michaels' influential statement of it in 'Bad Aboriginal Art'. Like Michaels, the anthropologists from the South Australian Museum who researched the background of 'Dreamings' worked closely with their contacts amongst the group of senior men who were painting in earnest at Yuendumu by the time preparations for the exhibition got underway in about 1987. There has since been a steady stream of catalogues and documentaries on the art movement, all describing the origins of Western Desert painting without any suggestion that the act of doing of these paintings had ever been considered in conflict with the values of Western Desert society. Maybe now that the art movement has achieved 'social legitimacy' ${ }^{27}$ most would prefer to forget the initial antiestablishment days at Papunya. But if those years when the Papunya painters were reviled as cultural delinquents are left out of the picture, it becomes impossible to understand the paths of uncompromising independence taken by so many of the founding artists over the past decade - with profound implications for the development of the company they had established. 'Papunya Tula: Genesis and Genius' held out the promise of a more finally nuanced history, but by focusing on the evolution of the company's image as constituted by whoever is painting for it at the time, it neatly side-steps the issue of what became of the founding fathers of Western Desert art.

\section{THE POSSIBILITY OF FORGERY}

Consequently, plagiarism is impossible in Western Desert painting. What is feared, instead, is thievery - the unauthorised appropriation of a design as well as the potential for such stolen designs to convey rights and authority to the thief. A forgery adequately executed may be no forgery. ${ }^{28}$

It seems incredible that anyone could declare plagiarising Western Desert painting an impossibility when the tourist sector is inundated with plagiarisations of its imagery. Michaels meant that it was impossible for a Western Desert artist to plagiarise (because under Warlpiri laws of intellectual property, every Warlpiri already has their own Dreaming designs to paint and everyone knows who has the right to paint what). But his unintentionally inflammatory choice of words reminds us that 'Bad Aboriginal Art' was written just before the tourist boom of the Australian Bicentenary celebrations fed into the beginning of the seemingly endless boom in Aboriginal art sales which within a decade had transformed Western Desert paintings into icons of the cool quarter million. This confluence produced, via the art history publications industry, the rash of infringements of Aboriginal art over which the landmark copyright cases of the 1990s were fought. Michaels' death in the same year that 'Bad Aboriginal Art' was published meant that he witnessed neither the victorious legal actions, brought by Indigenous artists, to establish their entitlement to the protection of the Australian Copyright Act - nor the response of the souvenir industry to these judgements of commissioning backroom

27 Eric Michaels, op cit, p62. 28 Ibid, $\mathrm{p} 68$.

$29 \mathrm{cf}$, Vivien Johnson et al, The House of Aboriginality, CD ROM, Macquarie University, 1998. designers to do their own versions. Plagiarised dots, tracks, concentric circles, $x$-ray kangaroos and barramundi were everywhere on everything during the 1990s: you could furnish a whole house with plagiarised Aboriginal art merchandise..$^{29}$ Could the possibility of these plagiarisations be comprehended within the framework Michaels had laid down in 'Bad Aboriginal Art'? Back in 1987, there was no Mabo and no Wik, ${ }^{30}$ no native title, not even the vague and 


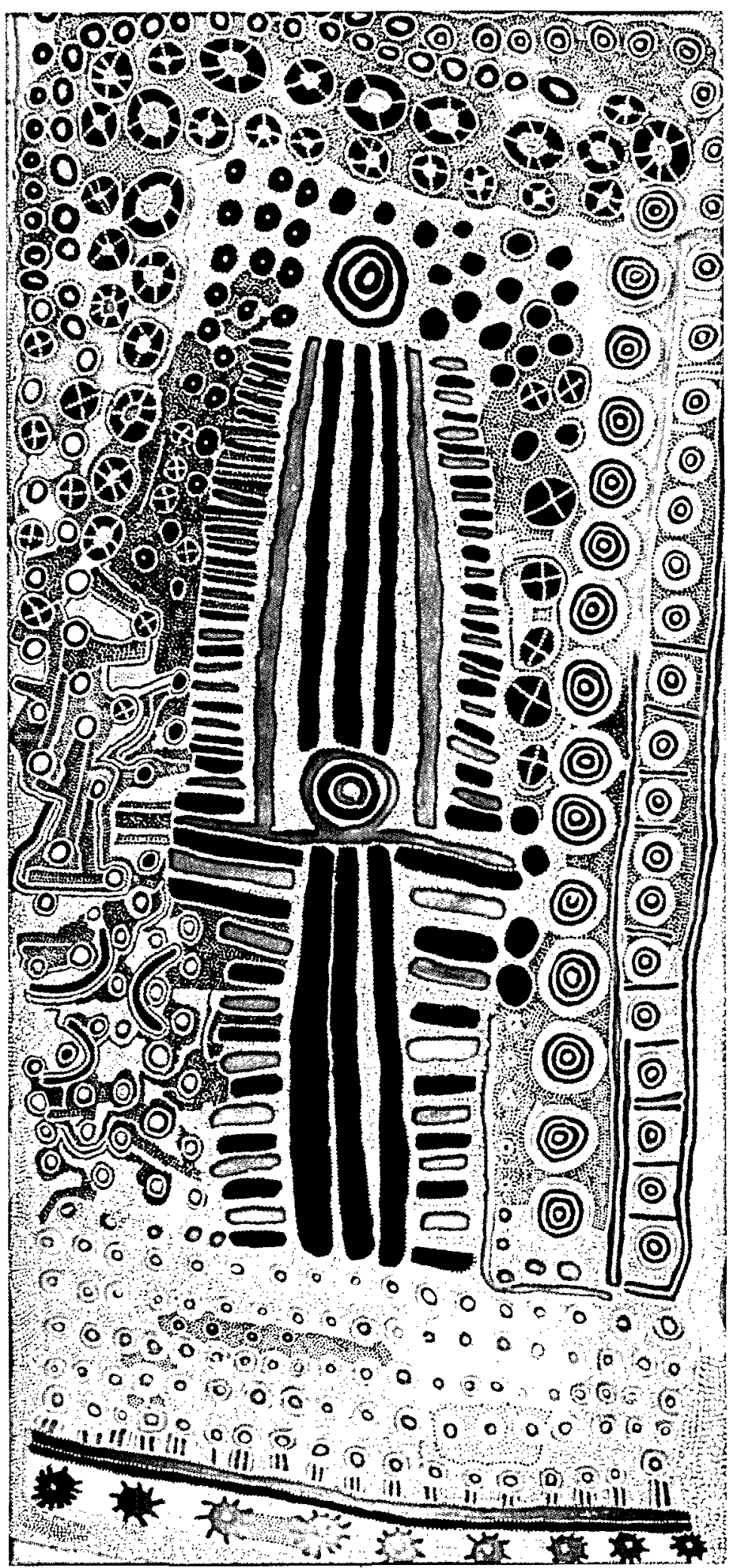

Paddy Jupurrurla Nelson Paddy Japaljarri Sims Kwentwentjay Jungarrayi Spencer Yanjilypiri Jukurrpa (Star Dreaming), 1985, synthetic polymer paint on canvas, $372 \times 171.4 \mathrm{~cm}$

Purchesed from gallery admission charges 1986, National Gallery of Australia, Canberra 
30 In June 1992, in the socalled 'Mabo' Judgement, the High Court of Australia rejected the doctrine that Australia was terra nullius at the time of European settlement. In 1996 a second landmark decision in a case initiated by the Wik peoples of Cape York found that native title could, under certain circumstances, co-exist with other interests in land, such as leasehold.

31 eg, 'Postmodernism, Appropriation and Western Desert Acrylics' in Postmodernism: $A$ Consideration of the Appropriation of Aboriginal Imagery, Forum Papers, ed Sue Cramer, Brisbane, Institute of Modern Art, 1989, pp 26-34.

32 Eric Michaels, op cit, pp 60-61.

33 'In all of these terms, 'primitive' art (particularly Aboriginal Australian paintings and specifically Warlpiri acrylics with which I am most familiar) poses certain intrinsic problems of valuation and evaluation because it involves very different creative and authorial practices.' Ibid, p 60 . soon-to-be broken promise of a treaty - just terra nullius, and Aboriginal art was an artistic terra nullius. Art world debates on appropriation with respect to Aboriginal art were focused on a couple of high profile non-Indigenous artists whose controversial excursions onto the terrain of Aboriginal art Michaels had vigorously defended elsewhere in his writings. ${ }^{31}$ The Working Party for the Protection of Aboriginal Folklore established in 1981 in the wake of Wandjuk Marika's agitation to stop unauthorised reproduction of Aboriginal art had not long since reached the conclusion, after four years of deliberation, that Aboriginal art could not be protected by the Australian Copyright Act because it didn't satisfy the criterion of 'originality'. It was folklore - a static body of designs whose origins were lost in the mists of time, rigidly transcribed from generation to generation - which is exactly how Michaels characterises the 'creative and authorial practices of Warlpiri acrylics' in 'Bad Aboriginal Art':

\begin{abstract}
Everyone in traditional society is effectively entitled to paint certain designs, not from particular notions of skill or talent (ie personal predispositions) but as a result of certain negotiated positions within systems of inherited rights and obligations. These design traditions are considered to originate in the collective past, and project towards an infinite, impersonal future. By necessity, the authority of the system would be compromised by an ideology of invention which singled out individual producers. ${ }^{32}$
\end{abstract}

As the anthropological orthodoxy of the day, the perception of the classical forms of Aboriginal art (ie, Western Desert acrylics and bark painting) as bound by unchanging rules set by the tribal authorities was able to exercise vital strategic influence in the copyright campaigns of the 1990s. Its acceptance underpinned the establishment of legal precedents like the concepts of 'cultural harm' and 'fiduciary duty' which recognise the reality of Indigenous regimes of intellectual property. But those same campaigns also reflected the reality of Aboriginal art's emerging status as Contemporary Art. It comes as a shock to realise that Michaels was here enumerating Western Desert painting's Otherness vis-à-vis contemporary art practices. ${ }^{33}$ Despite remaining pockets of eurocentrism that refuse to allow the concerns of 'traditionally oriented' Indigenous artists a place within capital ' $C$ ' Contemporary Art, the proposition that Aboriginal artists were just as entitled as any other contemporary artist in Australia to the protection of the Australian Copyright Act finally found acceptance in the courts because it had become self-evident. But in their judgements in these cases, the courts also ruled that cultural authority and 'authorial intent' could co-exist in one and the same expressive form. It is well to remember as 'Papunya Tula: Genesis and Genius' puts the seal of 'retrospectability' on Papunya Tula as Contemporary Fine Art that it is also always 'more than just art':

The European art world don't understand the individual in the Aboriginal art world. I've got to make my work look as my own, I've got to have my own originality. I can't make it look exactly like anybody else's. That's the whole point of Aboriginal art - each artist, you have to have you a style - not you have to, but you create you a style - as you learn it. Like with the dancing - if you're going to re-enact a brolga, you become a brolga - exactly, her movements and everything. You re-enact a spirit, you've got to become that. The dancing and the art is your whole life - you have to know your traditional artwork that ties in with the land that ties in with the creation - and where your boundaries, how far your ancestral 
creator travelled - it is all written in the art. That's what the traditional art means: the owner to the land. To a white man it might look like a pretty thing, but it's more than just art, it's everything tied in with how people are now and where we came from. ${ }^{34}$

In the decade after 'Bad Aboriginal Art' was written, Indigenous artists would challenge the anthropological orthodoxy in the courts, successfully claiming rights of authorship over the fruits of their own (re-)invention. Banduk Marika's words express a new perception of traditionally oriented forms of Indigenous art, which allows the possibility explicitly disallowed by Michaels, of the co-existence of tradition and innovation in Western Desert painting. Had he sat longer with the old men as they painted, Michaels might have learnt to take pleasure in his developing capacity to identify the work of particular artists, not from the Dreamings depicted in their paintings, but from the individuality of their depictions of them, recognising in this the cultural imperative delineated by Banduk Marika in this passage to 'make my work look as my own',' to have my own originality'. But it is likely that he would have read into such discriminations not the artists' conformity with the requirements of a traditional education, but their surrender to the dictates of the outside market. Such cynicism was uncalled for in 1988, but these are different times. Nothing could more clearly illustrate the loss of innocence in Aboriginal art between Michaels' time and our own than his playful excursions onto the terrain of rapprochement to explore the implications of the supposed inconsequentiality of the dots:

Dots label and authenticate desert acrylics for the European viewer, but may be inconsequential to the painters, for whom dotting might be likened to stripping in wallpaper. Dotting may be treated as a chore, assigned to junior painters. What if it should actually be discovered that a European was responsible for applying these dots? (At the instruction of an Aboriginal painter, of course. $)^{35}$

By current standards, that last qualification is both necessary and sufficient. Australian art audiences having been through the crisis of faith in the authenticity of Western Desert paintings provoked by just such a discovery (the Kathleen Petyarre/Ray Beamish affair), have 'mounted a myth based on the practices of classical and contemporary masters', ${ }^{36}$ and like Michaels they would accept such paintings as 'perfectly valid'. Rather more problematic these days is Michaels' inverse example. An uninstructed European (himself) concocts a design which one of the Yuendumu painters finishes off by putting in the dots and then sells at the Yuendumu store as his own painting $!^{37}$ Michaels could have used this anecdote to bolster his argument for the contemporaneity of Yuendumu painting by claiming the Aboriginal artist's response as an ironic, strikingly post-Modern acknowledgment of the fictive element of all representation. Today however, he might reflect more uneasily on the similarity between his second scenario and some of the claims made last year that private

34 Banduk Marika interviewed in July 1986, Sydney, by Vivien Johnson.

35 Eric Michaels, op cit, p 70. 36 Ibid, $\mathrm{p} 70$.

37 cf, ibid, p 70 . dealers were paying well-known Aboriginal artists a pittance to add a few authenticating dots to canvasses which they or other whitefellas working in backyard sweatshops had painted, and then selling them as the work of the authenticating artists. But he would probably be tickled pink to think that the value at auction of the painting in question, were it to re-surface today and be identified as the one discussed in 'Bad Aboriginal Art', would depend on its being by the hand of 'the late Eric Michaels'! 
38 In July 2000 an 'Adelaide art dealer' was committed for trial on 22 charges of 'obtaining benefit by deception' related to alleged forgeries of the work of Clifford Possum Tjapaltiarri, one of the founders of Papunya Tula Artists. cf. Vivien Johnson 'My Private Canvas' (forthcoming).

39 A Willis and T Fry, 'Art as Ethnocide: The Case of Australia', Third Text 5 , Winter 1988/9 and 'Not Such a Great Paint Job' Artlink vol 9, No.3, 1990.

40 Eric Michaels, op cit, p 68.

41 Ibid, p 56.

42 Ibid, p 56.

$43 \mathrm{~K} \mathrm{Aoki}$, 'Authors Inventors and Trademark Owners: Private Intellectual Property and the Public Domain', Part II, 18, Columbia ULA Journal of Law and the Arts, 191, 86, 1994.
Michaels assures us that his painting 'failed to look at all Warlpiri', but it is not his ineptitude as a plagiarist of the Yuendumu style that prevents him from. trying out the next scenario along the trajectory he has been exploring. What if someone were to copy one of the old men's individual styles without his knowledge or consent and pass the painting off on the art market as that old man's own work ${ }^{38}$ The problem for Michaels with this new scenario is that it relies on the artist's having invented a distinctive personal style which others may copy to produce paintings which can be passed off to the unwary or ignorant as the artist's own work. Michaels would have us believe that the individuation of artists by their personal styles rather than the collective labels of Papunya painting or Yuendumu painting undermines core values of Western Desert culture. There is a strain of thought here subsequently developed by Willis and Fry into a full-blown critique of the invasion of the delicate structures of traditional Aboriginal society by the bourgeois cancer of individualism. ${ }^{39}$ But to anyone - like Michaels - who has spent time in the company of the people of the Western Desert, the idea underpinning this criticism, that they are somehow devoid of personal identity, let alone a healthy dose of egotism, is laughable. When I first became involved with Papunya painting in the late 1970 s, the artists had refined their personal styles to the point where you could tell from the dots who had painted a picture. But outside of the commendation of a 'beautiful painting' ${ }^{40}$ by Johnny Warangkula - and then for its use of background dotting as signifying matter rather than the distinctive appearance of this artist's work, there is not one line in 'Bad Aboriginal Art' which recognises the element of individual style in Western Desert painting.

\section{PAPUNYA TULA}

I could be glib and remind Michaels that his mentor Baudrillard regarded brand names as 'the quintessential postmodern cultural good'. ${ }^{41}$ But forget the metaphors - of predictability, decay or postmodernity. Papunya Tula is quite literally a brand name, in exactly the sense that those who developed the common law of trademark intended: it stands 'for a set of qualities that the producer has instilled in the product by repeated delivery' ${ }^{42}$ Legal protection was granted to trademarks in the 19 th century as a form of intellectual property 'from a general background of seeking to protect the public from mistake, confusion, and deception about the source and quality of the products purchased in the market'. ${ }^{43}$ The need for such protections in the contemporary Aboriginal art market can hardly be denied - in fact, the perception of Papunya Tula Artists as the industry byword for secure provenance has played no small part in its return to unchallenged pre-eminence in the marketplace over the past few years - that, and its artists'seemingly infinite capacity for re-invention.

In the 20th century, particularly in the US, trademark law has developed away from the guarantees of quality and consumer protection in which it had its beginnings, to focus on the buying and selling of these intellectual properties, with little regard to public accountability. This tendency becomes more pronounced as the IT revolution transforms intellectual properties into the key commodities of the 21st century. However, Aboriginal artists have shown with the copyright campaigns that though a law may have become diverted in its operation from the purposes its makers intended, it can still be invoked in defence of the rights which it was originally framed to protect. The 
44 Rosemary Coombe, The Cultural Life of Intellectual Properties: Authorship, Appropriation and the Law, Duke UP, USA, 1998, p 61. heightened awareness of intellectual property in Aboriginal art fuelled by the artists' successful agitation for their legal rights to control reproductions of their images, has for obvious reasons been focused on copyright, but other forms of intellectual property may assume increasing importance as time goes on. Unlike copyright, which is no longer protected fifty years after the artist's death, a trademark is

potentially perpetual so long as it continues to be used and retains its distinction in the social imaginary. Unlike human authors, the corporation may live for ever, and its embodied identity in the trademark form shares its potential immortality and if assigned will survive even the corporate demise. ${ }^{4}$

'Papunya Tula: Genesis and Genius' is not only a retrospective of an art movement. It is also a million dollar promotion for Papunya Tula Artists Pty Ltd - which on top of the artistic triumphs of two generations of its artists is also the most enduring and successful commercial operation ever in the history of Indigenous cultural enterprises in Australia. Aboriginal owned and directed, its mainly non-Indigenous management has sustained over three decades an unbeatable record of quality product and culturally sensitive professional service to its artists and customers alike - a working model of black-white cooperation i.e. reconciliation. That's what Papunya Tula stands for today and 'Papunya Tula: Genesis and Genius' will ensure that it continues to prosper. In the (brand) name 'Papunya Tula' which Michaels reviled, the company's founders and all the artists and everyone who has kept the company going for the last thirty years, have created for the artists' descendants a valuable and permanent legacy. To maintain its value, all the artists and their management have to do now is 'carry on'. Paddy Carroll Tjungarrayi, who has painted for Papunya Tula Artists for 25 years, obliquely recognised this when, though not included in the retrospective, he agreed to sign my copy of the catalogue, adding his signature to the glorious jumble of names and crosses I had collected on its title page. 'PTA', he wrote. 